\title{
Secularization and the Imperative of Nigeria's Secularity
}

\author{
Pius Oyeniran Abioje \\ Ph. D, Department of Religions, University of Ilorin.
}

\begin{abstract}
Since the 1979 Constitution declared Nigeria to be a secular state, there has been prevalent objection to the declaration, and obvious violations of that constitutional stipulation are rife. This undermining of Nigeria's secularity status has not been without negative consequences. As from the first Islam-related Maitatsine uprising in Kano in 1980, and subsequent ones which likewise resulted in wanton destruction of lives and property, Nigeria continues to experience religious crisis, with particular reference to the Muslim-north. Several scholars have discussed the various religious crises. This study is not about "religious tolerance", "religious collaboration", or "religious understanding through dialogue", as already done by many religious scholars in Nigeria. It argues that religious sectionalism, rivalry, favoritism, and crises will persist in Nigeria, as long as the secularity status of the country is disregarded by the religio-political leaders. The research saw a situation in which some scholars miss-represent the policy of state secularity as an anti-religious policy, rather than one that is intended to engender and sustain religious justice, peace, unity, and social progress. The study is based on participant observation (in the sense that the researcher is domiciled in Nigeria), library consultation, and internet sources.
\end{abstract}

\section{Introduction}

Religious crisis occurs mainly in a religiously pluralistic society. Paradoxically, multiplicity exists also in some or many societies that have a single religion by nomenclature, such as Christianity or Islam, in form of denominations, sects, and factions. To forestall conflicts and maintain social cohesion in a religiously multiple or pluralistic society, such as Nigeria, state secularity seems imperative. In the case of the Western world, for instance, Cobb (1997:9) notes that:

Much of the intense religious feeling in the first half of the seventeenth century focused on particular formulations of the Christian faith. As a result, for half a century there were wars among competing Christian factions. The bloodshed was enormous. Increasingly, Christians viewed the passions that caused this situation as fanatical rather than as expressions of faith and began to look for a common ground among the competing factions. This was found in two places: nationalism and rationalism.

Obviously, the concepts of nationalism and rationalism in Cobb's statement imply state secularity. As he explains in the paragraph that follows the above quotation, the conflicting Christians henceforth felt loyalty and commitment to the well-being of their nations; they shifted "basic commitment from divisive religious institutions to political units", and stopped "the killing of neighbors"; the nation states "took-over primary responsibility from the churches", while "national governments were to regulate religious life within their boundaries". That no doubt describes the Western approach to religion in society till today, generally speaking.

The British colonial masters brought the same secularist approach to Nigeria. As Atanda (1989:184185) notes, the colonialists who proclaimed Nigeria as their Protectorate in 1900, amalgamated her into a political unit in 1914, and ruled the land till October 1,1960, as well as the succeeding nationalist governments never had a state religion, and so, one can conclude that state secularity was taken for granted. But, as Atanda further notes, Nigeria's 1979 constitution went beyond silence on religion, and states categorically, that "there would not be any state religion, and unequivocally declared the country a secular state." Similarly, section ten of the currently operative 1999 constitution states that "The Government of the Federation or of a State shall not adopt any religion as State Religion" (Ikogho, 2006:8). In a religiously pluralistic nation, such as Nigeria, with three principal religions, namely, African Traditional Religion (ATR), Christianity, and Islam, there seems to be no better alternative than state secularity, which forbids mixing religion with politics, and, thereby excludes politicization of religion. The regulation is not in doubt, but its violation is in vogue.

\section{Theoretical Framework}

This is an exercise in religio-political studies, since state secularity borders on separation of religion and state-running. Apparently, religion has been with humanity from time immemorial if not ab initio. As Smart (1981:11) notes, "Throughout history and beyond in the dark recesses of men's earliest cultures, religion has been a vital and pervasive feature of human life." Beyond that, Frankl (2000:14) exclaims that, "There is, in fact, a religious sense deeply rooted in each and every man's unconscious depths."Politics and politicization are not less primal, and it seems both religion and politics have been together both harmoniously and in conflict, 
depending on circumstances. Theoretically, this study argues that the prevailing religious climate in Nigeria requires adherence to the nation's secularity as stipulated in her constitution. While it does not object to interreligious dialogue that is advocated by some scholars, the study holds that dialogue works better in an atmosphere of socio-religious equity, which state secularity implies than in politicization of religion that is the order of the day in Nigeria, currently. State secularity is here conceived as the antidote to religious favoritism and injustice that are usually associated with sectionalism.

One sees the need to clarify the concepts of both secularism and secularization that some Nigerian scholars associate with rejection of God and religion, which smacks of calling the dog a bad name in order to hang it. Mala (1984:250), for instance, rightly notes that:

While pure secularism is anti-God and anti-religion, a secular state gives room for religious and ideological differences, including the recognition of God, which in Nigeria is our important common denominator. A secular state also discourages undue government interference in matters of belief-systems. To say that Nigeria is a multi-religious state and not a secular state is merely semantics.

Indeed multi-religiosity is the real reason a nation should opt for state secularity, but Mala does not appreciate the policy of state secularity beyond that statement on "recognition of God" and discouragement of "undue government interference". He does not even show any sign that he was aware of undue government interference with regard to how public funds were here and there spent on building churches and mosques, and sending some Christians and Muslims on pilgrimages, which contradict the policy of state secularity. He makes no reference to illegal politicization of religion which is the order of the day in Nigeria, and negates the policy of state secularity. Rather than emphasizing the values of state secularity which can promote religious equity, justice, and peace, he recommends "dialogue", which is extra-judicial and not easily enforceable, as "the only way" out of religious crises in Nigeria.

Similarly, some others, such as Alana and Bidmos, ignore and/or castigate the policy of state secularity and argue that dialogue is the solution to religious crises in Nigeria. Alana (1993:215-216) asserts that, "Various ways to detonate the 'time bomb' which Muslim-Christian rivalries have placed in the Nigerian society have been suggested over the years, except dialogue which is considered indispensable for Christians and Muslims in the country to agree on how to make their religions relevant to the Nigerian situation". Quite on the contrary, this study will demonstrate that state secularity is not about making religions relevant to society, but keeping them out of politics and public offices, so that the offices can serve the citizens equitably, irrespective of their individual religions. There seems to be no better way of taming religious sentiments and sectionalism temptation, without denigrating religious values.

Beyond canvassing for dialogue, however, Bidmos (2006:42) is of the view that "religion in its purity has not created any vacuum for secularism to fill", and that "the compartmentalization of life between religion and secularism cannot work". His preferred meaning of secularism is found in "the New Catholic Encyclopedia, Volume XIII", which defines "secularism as a system of social teaching or organization, which allows no part to religion or church". According to Bidmos, "It is clear from this definition that the purpose of secularism is to seek a substitute for religious influence in the process of managing affairs of man in his temporal abode," which is, in his own view, unacceptable to Islam and Christianity (pp. 34-35). Definitely, he has deliberately, inadvertently, or otherwise distorted the purpose of state secularity as will soon be demonstrated, below. Like Mala and Alana, therefore, Bidmos submits that "A critical examination of the religious climate in the country makes a strong case for Inter-Religious Dialogue", to resolve "the existing relationship between the Muslim and Christian communities and the attendant eruption of violence in different parts of the country" (p.8). Of course, the common denominator among the three scholars is lack of appreciation for the value and import of the policy of state secularity. While dialogue is good in itself, however, it cannot be enforced like the legalized state secularity which stipulates non-politicization of religion and demands religious freedom for every citizen. Rather than discussing religious plurality, Bidmos refers to "religion in its purity", which is farfetched and intractable in itself.

\section{History of Secularization}

The rationale behind this sub-heading is that a clearer understanding of what state secularity means may change peoples' attitude towards it, even though many powerful religio-political leaders seem to benefit from mass ignorance and confusion, and sometimes, the academia promotes both ignorance and confusion. Cobb has been quoted (above) as explaining that secularization emerged as a consequence of hostile and bloody religious bigotry in Europe in the first half of the seventeenth century. Schreck (1987:81) similarly attributes it to a situation in which "the people of Europe became tired of wars of religion." According to Wikipedia (2012), the person who coined the word "secularism" was a British writer, George Jacob Holyoake (1817-1906). The words "secularism" and "secularization" are used interchangeably in the Wikipedia and here. 
One discovered that secularization predates the seventeenth century. In the words of Lyon (1998:634635), "secularization has to do with the splitting apart of church and state which has occurred since medieval times". Since then, as Lyon further notes:

Although secularization has happened in various ways (the USA hardly ever had strong church-state collusion, France abolished such collusion with a revolution, Britain still has national churches, but also a large denationalized sector), the result is similar. Other voices vie for attention in the marketplace of ideologies. Organized Christianity has little say in the affairs of state, or, indeed, in public life in general.

Unfortunately, "church-state collusion" is still the order of the day in Nigeria, so to say. The collusion expresses itself in the mutual support sought and received among religious and political rulers, with particular reference to Christian and Muslim leaders whose religions are majority and dominant, socio-politically and economically. Many of the political rulers spend public funds on church and mosque related matters, and the religious leaders concerned praise them, and overlook the unbridled corruption in the land. Both parties oppose the policy of state secularity, because that may end the corruption from which they are deriving unholy benefits. That is in tandem with what Lyon notes (above) that "France abolished such collusion with a revolution", since the powerful beneficiaries would always like to maintain the status quo, otherwise called business as usual.

The foregoing has made it abundantly clear that state secularism is not about denial of God and religion, but engendering religious sanity in a religiously pluralistic society, such as Nigeria. Lyon notes that the term "secularization" has its origin in the Peace of Westphalia (1648), and it designates "the transfer of ecclesiastical property into princely hands". He emphasizes that "the loss of the churches' temporal power is one of the most important dimensions of 'secularization'." He acknowledges that "the concept is bedeviled by controversy", but its most basic aspect is "the splitting apart of church and state." Splitting religion and state apart is imperative in Nigeria where religious conflict and favoritism are rife.

\section{The Failure of Nigeria's Secularism}

Literature has revealed that secularization is a highly controversial concept (Lyon, 1998:634-635). The reason is either that many scholars have no knowledge of its real history or raison d'être, or that insincerity and/or religious prejudice stand on their ways to an objective evaluation of what secularization is all about. With specific reference to Nigeria, Adegbite (internet 2012) discusses the various controversies trailing the country's secularity status. He quotes one "Omotola Jeremiah Shola, a political scientist and public administration specialist", who defines secularism as "an ideology that holds that religious issues should not be the basis of politics (or in the extreme) that religion has no place in public life." Thus, as Adegbite quotes Shola as noting, secularism has nothing to do with denial of God or religion, and he concludes that "essentially, secularism seeks to preserve the religious neutrality of government and cultures". The focus of Adegbite's research is the controversy on the constitutionality of Nigeria's secularity. Although the constitution states in its Section 10 that "The Government of the Federation or of a State shall not adopt any religion as State Religion", it does not mention the phrase "secular state" anywhere, and there has been no judicial interpretation that declares that the Constitution's statement implies that Nigeria is a secular state. After his explorations, Adegbite came to this conclusion

Apart from the clear wordings of the provision of section 10, the margin note to the section reads Prohibition of State Religion. Therefore with the aid of the margin note and the clear wordings of the section, it becomes much easier to infer the intention of the drafters of the constitution which is to separate state from religion. This is to ensure that religion as a private matter does not stray into public affairs. The state must not adopt any religion as one to influence its official decisions or as one being promoted with state funds. It is a settled principle that where the wordings of a constitutional provision are unambiguous, a court has a duty to accord to that provision its ordinary meanings. It is on this basis that it is correct to say that the drafters of the constitution intended Nigeria to be a secular state.

The failure of Nigeria's secularity to guarantee religious equity, justice, and peace can, therefore, not be blamed on any ambiguity on the part of the drafters of the Constitution, but on both ignorance and deliberate distortion of what state secularity stands-for. Religious causes are "promoted with state funds" by many of the rulers, contrary to the dictates of state secularity, and if that is to persist, interested persons have to continue to explain away the constitutional provision on state secularity. Imperialistically-minded politico-religious rulers who live on religious sentiments can hardly avoid resistance to the policy of state secularity, and they will never willy-nilly stop whipping-up religious sentiment under the guise of being seriously Christian or Muslim. No wonder France had to eliminate the collusion of politico-religious leaders through Revolution, before she could establish and enjoy her secularity status. Ake (2003:9) notes how "the French Revolution was a phenomenal emancipatory struggle which heralded the beginning of the modern polity and the modern world", as "it changed the world profoundly by introducing remarkable innovations such as universal citizenship and the idea of inalienable rights of humans and citizens". 
The foregoing implies also that the imperialistically-minded politico-religious rulers will continue to deliberately encourage religious bigotry, rivalry, and attendant violence to keep themselves afloat. Historically, according to the Wikipedia (2012), "the process of secularising states typically involves granting religious freedom, disestablishing state religions, stopping public funds to be used for a religion, freeing the legal system from religious control, freeing up the education system, tolerating citizens who change religion or abstain from religion, and allowing political leadership to come to power regardless of religious beliefs." That, according to the Wikipedia, is the stuff that makes the free world to be truly free. If a leader does not emerge based on religious sentiment, he or she is not likely to indulge in religious favoritism. What is more, the principle of state secularity makes religious favoritism illegal. Obviously, Nigeria's Constitution does not promote atheism, but religious equity based on governmental non-involvement in religion. One cannot but conclude that the goal of many opponents of state secularity is to politicize religion, so as to access public funds, which is creating avoidable religious crises, as it is currently the case in Nigeria.

Division along religious lines has the potentiality to prevent a people from uniting to demand their socio-political rights and accountability from their rulers. Hence the politico-religious leaders who are beneficiaries of politicization of religion may never support the idea of state secularity, and so the mass of the exploited need to shun religious bigotry and unite around what makes for an equitable and just society, towards progress. There seems to be no better alternative to state secularity, as obtains in the developed nations of the world. Painting state secularism as atheism should be discountenanced, since there is no such indication in Nigeria's Constitution anyway. Beyond that, Wikipedia (2012) discovered that not all legally secular states are completely secular in practice. The example given is that of France, where "many Christian holy days are official holy days for public administration, and teachers in Catholic schools are salaried by the state", most likely because they are not profit-making schools. But using religion as a means of divide and rule, which is creating violence and bloodshed as in Nigeria hardly exists in serious secular states. The Wikipedia page indicates further that in India, where, like in Nigeria, airfare subsidy is given for Muslims going on Hajj, the government has found it too burdensome, financially, and is trying a restructuring that will take about seven years, which will involve "the richer Hajis" paying "a premium for the poorer pilgrims." If that is the real picture, it is difficult to see how it will work in practice. In Nigeria, the government at all levels gives subsidy for some Christians and Muslims to go on pilgrimage. Asae-Brown (2012, internet) notes how in the 2012 budget, the Federal Government of Nigeria earmarked N1.34 billion for pilgrimage sponsorship, based on which the National Hajj Commission got N765, 654,846, while the Christian Pilgrim Commission got N576,707,504. That is done in misplacement of priority, since Hajj is said to be meant for only those who could afford it (Bakare, 2012, internet), and there is no indication that Christianity has any pilgrimage obligation.

Government paying for some Christian and Muslim pilgrimages is a principal way by which state secularism has failed in Nigeria, and the political rulers use that, as well as different forms of "gifts" to woo many principal religious rulers. It is public knowledge that public funds are also spent on religious festivals of all sorts, and some public officers abuse their positions to build places of worship for one religious community or another to gain political patronage and cheap popularity. Such sectionalism and misappropriation of public funds can only stop if Nigeria sticks seriously to her secularity status that forbids politicization of religion. It is politicization of religion that is usually responsible for violent religious conflicts as well. Indeed, it cannot be said that state secularity has failed Nigeria, since it has not been tried.

\section{The Limitation of Inter-Religious Dialogue}

Dialogue connotes peaceful inter-communication. As for its root, Fasola (1999:27) notes that it derives from "the Greek word dialogos, which means a conversation". He quotes Reuel Howe as stating that "every man is a potential adversary, even those whom we love, only through dialogue are we saved from enmity toward one another." In his own explanation, Fasola expresses the view that:

Dialogue is to love, what blood is to the body. When the flow of blood stops, the body dies. When dialogue stops love dies and resentment and hatred are born. But dialogue can restore a dead relationship. It can bring into being once again a relationship that had died.

That is reminiscent of a Yoruba maxim that if war will come, it will be through some discussion, and if war will cease, it will be through some discussion. One would concur, therefore, that dialogue is indispensable in social interaction and inter-personal relationships. With specific reference to inter-religious harmony, dialogue represents the quest for peaceful co-existence.

Two forms of inter-religious dialogue have been identified in Nigeria, informal and formal. According to Onaiyekan (2011:11-14), it is the informal dialogue that has been maintaining peace in many Nigerian communities, notwithstanding the "occasional moments of madness". At the formal level, as Onaiyekan further notes:

The most well-known forum for inter-religious dialogue in Nigeria is of course the Nigerian Interreligious Council (NIREC). This is a forum where 25 delegates gather from each of the umbrella organizations 
of our two major faith communities: the Supreme Council for Islamic Affairs (SCIA) for Muslims and the Christian Association of Nigeria (CAN) for Christians.

Onaiyekan, who is the Catholic Archbishop of Abuja, a former CAN president, and a founding member of NIREC explains that Christians initiated the Council (NIREC) due to "a lot of complaints in Christian circles about how Muslims are alleged to be taking advantage of Christians in many areas of national life", and "a perceived sense of persecution of Christians in communities that are predominantly Muslim". Thus, one may not be wrong to think that political and economic interests constitute ulterior motives in Muslim-Christian faceoffs in Nigeria, generally speaking. At the same time, dialogue tends to be impossible where there is no goodwill or mutual disposition towards peaceful co-existence. It can only work to the extent to which the interlocutors are willing to reconcile, since, unlike the policy of state secularity, it has no legal teeth.

\section{The Prospect of Theological Dialogue}

The argument has been rife for quite some time that understanding one another's faiths would lead to mutual appreciation and cessation of hostility. Brown (1997:64) notes, for instance, that: "Elimination or limiting misunderstandings, so as to lay solid foundations for enduring harmony, requires a thorough familiarity with the concepts and practices which have framed the legal and political perspectives of our neighbours over centuries of accumulated custom". Likewise, Onaiyekan (2011:7) holds that "it is necessary to open our hearts to the way of life of the other so as to understand him or her better", for "it is only then that we can respect one another in our differences". I subscribe to Onaiyekan's other argument that respecting one another is much better than mere toleration of one another. But, knowing and understanding are one thing, personal disposition and deep-seated prejudice, together with clique mentality aimed at political and economic gains are different things entirely that can stand on the way of successful dialogue and peaceful co-existence.

Several scholars have identified some areas of permanent doctrinal incompatibility between Christians and Muslims. Brown (1997:97) notes, for instance, that the Muslims' perception of some key Christian doctrines is negative, such as with "the doctrines of the Trinity and the Incarnation, which so manifestly contradicted the Qur'an's affirmation of God's unique essence and absolute otherness." He notes further on the Muslims that:

Although they were impressed by the piety of many Christians, including the monks of Sinai, the Muslims could not endorse the austere and celibate life-style practiced by the hermits, and the dictum of "no monkery in Islam' has survived through the ages. Even the most ascetic Muslim mystics have been married, and no monastic movement has ever appeared in the Islamic world. Furthermore, Islam has had neither ordained priesthood nor special hierarchy, but has simply assigned leadership to persons of recognized piety and scholarship (though among the Sufis spiritual authority has normally been transmitted by chains of sponsors or pirs.

On the other hand, Fashola (1999:3) indicates some areas of Christian negative perception of Islam. One of the points he notes is that an early Christian, John of Damascus, viewed Islam as "a kind of Christian heresy, a kind of Christian deviation, an early day Jehovah Witness or Unification Church, a heresy from within Christianity which has gone in a different direction". Of course, it is generally believed that the Prophet Muhammad had interactions with both Christians and Jews before the commencement of his ministry, but Christians and Muslims may never agree on whether, how, and to what extent if at all the Jewish and Christian Scriptures influenced the Prophet. Yet another scholar, Coutts (1990:31), notes that:

Clearly the two faiths differ about the places to be given to Jesus and Muhammad. The Christian can recognize Muhammad as a prophet; he cannot see in him the prophet who completes the work of all the rest. On the other side, it has been said that 'the followers of Muhammad profess great respect for our Lord, and are more ready to forgive Peter for being a fisherman than (many Christians are) to forgive Muhammad for being a camel driver'. Yet, 'great respect' is not the same thing as loving adoration. Islam clearly denies that in Jesus we see the Son of God, 'full of grace and truth.'

There seems to be no amount of understanding and dialogue that can neutralize the above-stated deep seated contradictory beliefs. Knowledge and understanding are good in themselves, but knowing and doing, knowledge and good will, knowledge and ethics, can be many poles apart. Hence it seems reasonable to hold that the basic target of dialogue should not be doctrines that are peculiar to the diverse religions; doctrines which, by the virtue of their perceived peculiarity, embody seeds of disagreement, tension, violence, and disunity. In one's view, inter-religious dialogue should restrict itself to peaceful co-existence issues, such as processions and other programmes that may require negotiation and concession on time and space of events, not about Christian Trinity, Muslim polygamy, or ATR's “idols”, for instance. Of course general knowledge of oneanother's doctrines can be good and useful for healthy relationship, but ignorance of another person's beliefs should not be an excuse to fight him or her. That is why state secularity which stipulates religious freedom and non-politicization of religion surpasses dialogue that has no legal obligation, and so cannot be enforced. State 
secularity can create a conducive atmosphere and an elixir to inter-religious dialogue, particularly since whoever creates religious crisis in a secular state is expected to be penalized under the rule of law.

\section{Recommendations}

Based on the foregoing, one would recommend as follow:

1. Nigerians should respect the country's secular status, as enshrined in the constitution, so as to maintain freedom of religion, equity, unity, and fraternity, without which democracy and civilization of love are endangered; religious sentiments and favoritism should not be allowed to bedevil public offices.

2. Religious leaders should educate their followers on religious freedom and the need to respect other religionists and their beliefs; hold peace dialogue, and maintain social harmony, as necessary in a religiously pluralistic society, such as Nigeria.

3. Security agents should be well-equipped to handle, judiciously and impartially, situations in which some malevolent and belligerent religious practitioners are ill-disposed to peaceful co-existence.

\section{Conclusion}

The study has examined the problem of abuse of religion in Nigeria, with the objective of finding ways by which religious freedom, equity, justice, peace, and progress can thrive in the country. It discovered that the constitutional measure, which declares Nigeria a secular State was, for the most part, undermined, and politicization and abuse of religion constituted the order of the day. The concept of secularism itself has been misrepresented as atheism in several quarters, and that misrepresentation tended to scare many Nigerians who are theistically-inclined. Yet, in line with the principle of normal state secularity, the Nigerian Constitution does not order that there shall be no religion; what it forbids is politicization of religion or whatever can be termed an "official religion".

Having denigrated, depreciated, or castigated the policy of state secularity, some Nigerian scholars recommended inter-religious dialogue as "the only way" by which religious peace could reign in Nigeria. This study argues, however, that inter-religious dialogue works better in a secular state that disallows politicization of religion, and promotes religious equity, justice, and peace towards holistic social progress. The policy of state secularity is thus conceived as the primal antidote to religious crises in a religiously pluralistic society, such as Nigeria. The violation of the policy of state secularity, as discovered in Nigeria, promotes religious upheaval through favoritism, lack of social accountability, corruption, and misappropriation of public funds to advance religious causes that should be funded by private interests. The opponents of the policy of state secularity are perceived as powerful persons (mainly Christians and Muslims) who benefit from politicization of religion, or persons who are blinded by religious sentiment and emotion, without objective analysis. Basically, the study recommends compliance with the policy of state secularity as a sine qua non for religious sanity in Nigeria.

\section{References}

[1] Adegbite, Kehinde. 2012. "Is Nigeria A Secular or Non-Secular State?”, on http://www.nigerianmuse.com/20120525094823zg/nmprojects/sovereign-national-conference-snc-project/is-nigeria-a-secular-or-non-secular-state/ copied 30/10/2012.

[2] Ake, C. 2000. The Feasibility of Democracy in Africa. Dakar: Council for the Development of Social Research in Africa (CODESRIA).

[3] Alana, Olu. E. 1993. "The Relationship between Christians, Muslims and Afrelists in History, with particular Reference to Nigeria", in Abubakre, R.D., Yahyah, M.T., Akanmidu, R.A., and Dopamu, P. Ade. (eds.), Studies in Religious Understanding in Nigeria. Nigerian Association for the Study of Religions, pp.215-226.

[4] Asae-Brown, F. 2012. "Pilgrimage on Government Budget", Business Day, Wednesday, 17 October, 2012, http://businessdayonline.com/NG/index.php/analysis/features/46010-pilgrimage-on-government-budget.

[5] Atanda, J. A. 1989. "Conclusion, Paradoxes and Problems of Religion and Secularism in Nigeria: Suggestions for Solution". In Atanda, J. A., Ashiwaju, G, and Abubakar, Y. (eds), Nigeria since Independence, the First 25 Years, Volume IX: Religion. Ibadan: Heinemann Educational Books (Nig.) Ltd., pp. 184-194.

[6] Bakare, F. 2012. "Government's sponsorship of holy pilgrimages is sheer insanity", being a reaction to "Hajj sponsorship by government is another avenue to steal public funds" - Kano's Governor Kwankwaso: A reader's comments, Fatai Bakare, http://emotanafricana.com/2012/08/13/nigerian-governments-sponsorship-of-holy-pilgrimages-is-sheer-insanity/, submitted on 2012/08/13 at 12:43 pm (copied on Nov. 6, 2012)

[7] Bidmos, M. A. 2006. Inter-Religious Dialogue: The Nigerian Experierience. Lagos: Panaf Publishing, Inc.

[8] Brown, Stuart. 1997.The Nearest in Affection: Towards A Christian Understanding of Islam. Ibadan: Sefer.

[9] Cobb, John B. 1997. Reclaiming the Church: Where the Mainline Church Went Wong and What to Do About It. Kentucky: Westminster John Knox Press.

[10] Coutts, John. 1990. Our Faith and Theirs: The Christian Looks at Other People's Beliefs. London: Challenge Books, 1990.

[11] Fashola, L. F. 1999. Dialogue: Conflict or Co-operation? An Appeal for Change in Christian-Muslim Relations for the New Millennium. Ibadan: Samtop Printing Company, 1999.

[12] Frankl, ViKtor E. 2000. Man's Search for Ultimate Meaning: A Psychological Exploration of the Religious quest. New York: MJF Books.

[13] Ikogho, Joseph. 2006. Nigerian Constitution with Topic Finder: Lagos: Law View Consult, 2006.

[14] Lyon, D. 1998. "Secularization", in Ferguson, Sinclair B., and Wright, David E. (eds.), New Dictionary of Theology. Illinois: InterVarsity Press, pp. 634-236. 
[15] Mala, Sam Babs. 1984. "Religious Pluralism in Nigeria: The way Out and Factors Favouring It". In Mala, Sam Babs and Oseni, Z. I., Religion, Peace and Unity in Nigeria. Ibadan: Nigerian Association for the Study of Religions, pp. 242-263.

[16] Onaiyekan, John. 2011. Dividends of Religion in Nigeria. Ilorin: Department of Religions, University of Ilorin.

[17] Schreck, A. 1987. The Compact History of the Catholic Church. Michigan: Servant Books.

[18] Smart, N. 1981. The Religious Experience of Mankind. Glasgow: William Collins \& Sons Co Ltd.

[19] Wikipedia. 2012. "Secular state". http://en.wikipedia.org/wiki/Secular_state copied 30/12/2012. 